\title{
JURISDICTION BY TRICKERY: ENTICEMENT FOR SERVICE OF PROCESS
}

$I_{1}$ IN ORDER to induce a defendant to enter a jurisdiction and thereby subject his person to the process of its courts; a plaintiff may well be tempted to resort to underhanded means. ${ }^{1}$ The universally stated rule, however, is that service of process, thus procured, is vulnerable to attack, and it will be set aside upon proper application. ${ }^{2}$ This relief is accorded not because the circumstances surrounding the service have deprived the court of jurisdiction, but rather because the court will not sanction, even inferentially, such abuse or degradation of its process. ${ }^{3}$ Application

\footnotetext{
${ }^{1}$ Commercial Mutual Accident Co. v. Davis, 213 U.S. 245 (1 g09); Fitgerald Construction Co. v. Fitzgerald, 137 U.S. 98 (1890); Williams ads. Reed, 29 N.J.L. 385 (1862). See In re Cash, 383 Ill. 409, 50 N.E.2d 487 (1943); Miller v. Acme Feed Inc., 228 Iowa 861, 293 N.W. 637 (1940); Neotex Mfg. Co. v. Eidinger, 250 App. Div. 504, 294 N.Y. Supp. 767 (1937); Shillman v. Toulson, 211 App. Div. 336, 207 N.Y. Supp. 296 (1926); Bernstein v. Hakim, 126 Misc. 582, 214 N.Y. Supp. 82 (1926); Van Donselaar v. Jones, 195 lowa 1081, 192 N.W. 22 (1923); Saveland v. Connors, 121 Wis. 28, 98 N.W. 933 (1904); Abercrombie v. Abercrombie, 64 Kan. 29, 67 Pac. 539 (1902); Pilcher v. Graham, 9 Ohio Dec. 825 (1899); Toof v. Foley, 87 Iowa 8, 54 N.W. 59 (1893); Heston v. Heston, 56 N.J.L. 235, 28 Atl. 8 (1893); Van Horn v. Great Western Mfg. Co., 37 Kan. 523, 15 Pac. 562 (1887); Havener v. Heist, 9 Phila. 274 (County Ct., Pa. 1873); Dunlap \& Co. v. Cody, 31 Iowa 260 (1871); Marsh's Adn'r. v. Bast, 29 N.J.L. 385 (1862). These are but a few of the cases which have dealt with the problem. Of the thirty-two jurisdictions which have, a few have done so in the situation where fraud is used to obtain jurisdiction over defendant's property. Presumably, however, the court would reach the same result in a personal jurisdiction situation. See for example, Guardian Management Corp. v. Huffman, Mun. Ct. App. for D.C., 61 A.2d 472 (1948); Oklahoma Industrial Finance Corp. v. Wallace, 180 Okla. 363,69 P. 2 d 362 (1937); Abel v. Smith, 351 Va. 568, 144 S. E. 616 (1928); Siro v. American Express Co., 99 Conn. 95, I21 Atl. 280 (1923); Sessoms Grocery Co. v. International Sugar Feed Co., 188 Ala. 232, 66 So. 479 (1914); Deyo v. Jennison, ro Allen 410 (Mass. 1865); Timmons v. Garrison, 28 Tenn. 147 ( 1843 ). Jurisdiction thus obtained is not usually exercised. Jurrisdiction Over Persons Brought Into a State by Force or Fraud, 39 YAle L.J. 889 (1930); Stumberg, Principles of Conplict of Laws 7 I (1937); Goodrich, Conflict of LAWs \& 78.4 (3d ed. 1949).

2 Restatement, JUdGMents $\$ 15$, comment b (1942); Restatement, Conflict of Laws $\S 78$, comment d (1934); Beale, Conflict of Laws $\$ 78.4$ (1935).

${ }^{3}$ See Commercial Mutual Acc. Co. v. Davis, 213 U.S. 245 (1909); Taylor v. McCool, 183 Tenn. I, 189 S.W.2d 8 I7 (1945); Nicholson v. Gulf, Mobile \& Northern R. Co., I 77 Miss. 844, 172 So. 306 (1937); Battelle v. Youngstown Rolling Mill Co., 84 Tenn. 355 (1886); Gregory v. Howell, 118 Iowa 26, 91 N.W. 778 (1902); REsTATEMENT, Conflict of LaWs $\S 78$, comment d (1934). See also cases cited note 2 supra.
} 
of this rule in all but the most stereotyped situations, however, has confronted the courts with many difficulties.

Illustrative is the recent case of Tickle v. Barton. ${ }^{4}$ There, the nonresident defendant had duly objected to his service in the action pursuant to West Virginia's nonresident motorist statute. ${ }^{5}$ While a ruling in this matter was pending, the plaintiff, representing himself as a spokesman for a banquet committee, invited the defendant to attend a dinner within the jurisdiction. When the defendant, having accepted the invitation, appeared, he was served with process personally. The Supreme Court of Appeals of West Virginia, affirming the court below, vacated this service. Two judges dissented, however, observing that while the rule applied by the majority was a salutary one, the inferences that could reasonably be drawn from the facts of the instant case did not bring it within the "influence" of that rule. ${ }^{6}$

This divergence of judicial opinion echoes, to some extent, similar conflicts in other jurisdictions, ${ }^{7}$ and indicates a reappraisal of those

\footnotetext{
95 S.E.2d 427 (W.Va. 1956).

- Defendant objected by a plea in abatement and issue was joined on this plea.

- Tickle y. Barton, 95 S. E. 2d 427, 433 (W.Va. 1956).

${ }^{7}$ On the one hand are the cases in which the court has found a trick but refused to exercise its jurisdiction. Those cases include situations where plaintiff's agent performs the trick, Goss v. Hall, 125 Ind. App. 25, II7 N.E.2d 649 (1952); Empire Mfg. Co. v. Ginsburg, 253 Ill. App. 242 (1929); Carpenter v. Spooner, 2 Sandf. 7 I7 (N.Y. I850); plaintiff's friend performs the trick as a favor to plaintiff and informs plaintiff where and when defendant can be found, Blandin v. Ostrander, 239 Fed. 700 (2d Cir. 1917); plaintiff forges a special invitation to the defendant, Steiger v. Bonn, 4 Fed. 17 (C.C.D.N.J. I 880). See also Wanzer v. Bright, 52 Ill. 35 (1869). Plaintiff takes advantage of defendant's suggestion that defendant come to plaintiff's jurisdiction, Ultcht v. Ultcht, 126 Atl. 440 (N.J. Ch. 1924); plaintiff conspires to make a resident the agent of a non-resident defendant, Frawley, Band \& Wilcox v. Pennsylvania Casualty Co., 124 Fed. 259 (C.C.M.D. Pa. 1903); plaintiff conspires with one defendant in order to get others, Nicholson v. Gulf, Mobile \& Northern R. Co., 177 Miss. 844, 172 So. 306 (1937); Taylor v. McCool, 183 Tenn. I, I89 S.W.2d 817 (1945); plaintiff arranges to have a deposition taken in his jurisdiction in order to get furisdiction of defendant's person, Peel v. January, 35 Ark. 331 (1880). Compare Bowes v. Superior Ct. of Alameda County, 124 P.2d 667 (Cal. App. 1942); plaintiff begins attachinent proceedings causing defendant to make a general appearance, Economy Electric Co. v. Automatic Electric Power \& Light Plant, 185 N.C. 534, II8 S.E. 3 (1923). Compare Copas v. Anglo-American Provision Co., 73 Mich. 541, 41 N.W. 690 (1889); plaintiff and defendant agree to trial without jury. When defendant appears, according to the terms of the agreement, plaintiff serves him with process and demands jury trial, Graves v. Graham, 19 Misc. 618, 44 N.Y. Supp. 415 (1897); plaintiff keeps a box of summons on hand for delinquent debtors who have been requested to meet with plaintff for purpose of settlement, Baker v. Wales, 3 Jones \& Sp. 403 (N.Y. 1873); plaintiff uses the criminal processes to obtain civil service and/or plaintiff's friends accommodate plaintiff by bringing defendant within the desired jurisdiction, Tuggle $v$.
} 
factors, articulated and otherwise, which govern decisions in this context.

A survey of the cases reveals that courts have generally been content to be guided by the results of a somewhat mechanically applied "fraud test" instead of inquiring into the degree of acceptability of the questioned conduct. ${ }^{8}$ Accordingly, a defendant need but establish the existence of the technical elements of fraud to persuade the court to decline jurisdiction. In brief, this would entail proof that the defendant had been "induced" to enter the jurisdiction by the misrepresentations of

Sutton, $260 \mathrm{Ky} \cdot 304,84$ S.W.2d 1017 (1935); Bowman v. Neblett, 24 S.W.2d 697 (Mo. App. 1930). See also Klaiber v. Frank, 9 N.J. 1, 86 A.2d 679 (1952); Town of Hainden v. Collins, 85 Conn. 327, 82 Atl. 636 (1912); Byler v. Jones, 79 Mo. 261 (1883); McNab v. Bennett, 66 Ill. 157 (1872); Blair v. Turtle, 5 Fed. 394 (C.C.D.Neb. 1881); Rutledge v. Krauss, 73 N.J.L. 397, 63 Atl. 988 (1906); Towsend v. Smith, 47 Wis. 623, 3 N.W. 439 (1879); Williams v. Bacon, ro Wend. 636 (N.Y. 1832 ); Wells v. Gurney, 8 Barns \& C. 769, 108 Eng. Rep. 1229 (K.B. 1828 ).

On the other hand are cases in which the court has failed to find sufficient trickery to enable it to exercise jurisdiction. Included in this group of cases are situations where defendant's presence is the result of an invitation extended by several persons including an einployee of plaintiff, Ex parte Taylor, 29 R.I. 129, 69 Atl. 553 (1908); plaintiff asks her former husband to come to see their child and subsequently serves bim with process, Guzzetta v. Guzzetta, 137 N.E.2d 419 (Ohio 1956); plaintiff decides to sue defendant after defendant has started into plaintiff's jurisdiction at the request of plaintiff, Crandall v. Trowbridge, 170 Iowa 155, 150 N.W. 669 (1915); plaintiff takes advantage of defendant's presence caused by an attempted settlement instigated by a third person, Union Sugar Refinery v. Mathieson, 24 Fed. Cas. 682, No. 14398 (C.C.D. Mass. 1864); plaintiff takes advantage of defendant's suggestion that defendant come into plaintiff's jurisdiction, Lingo v. Reichenbach Land Co., 225 Iowa I I2, 279 N.W. 12 I (1938); plaintiff persuades defendant to come for talks and serves bim upon arrival, Watkins v. North American Land \& Timber Co., 20 T.L.R. 534 (1904); plaintiff uses a director's meeting for the sole pnrpose of obtaining jurisdiction, $\mathrm{Na}$ tional Paper Corp. v. Scheek, 47 Lack. Jur. I89 (County Ct., Pa. 1946); trustees' meeting, Iams v. Tedlock, 110 Kan. 510,204 Pac. 537 (1922); plaintiff assures defendant that a suit will be brought in one state and serves him in another, McLain v. Parker, $88 \mathrm{Kan} .717,129$ Pac. 1140 (19.3); defendant yields to a request by plaintiff that he defend his property in an attachment proceeding begun for the sole purpose of gaining personal jurisdiction, Duringer v. Moschino, 93 Ind. 495 (1883); plaintiff causes a deposition to be taken which defendant attends, Jaster v. Currie, I 98 U.S. 144 (1905).

See generally the cases cited infra, notes 9-12, which are typical examples of this narrow approach.

- See Schwartz v. Artcraft Silk Hosiery Mills, Inc., r to F.2d 465 (2d Cir. 1940); Cavanagh v. Manhattan Transit Co., 133 Fed. 818 (C.C.D.N.J. 1905); Strong v. Strong, 299 P.2d 148 (Okla, 1956); Gampel v. Gampel, I14 N.Y.S.2d 474 (1952); Stephens v. Thomasson, 63 Ariz. 187, 160 P.2d 338 (1945), Margos v. Moroudas, I 84 Md. 362 , 40 A.2d 816 (1945), noted in to MD. L. REv. 80 (1949); Voltz v. Tutt, 12 K.. L. Rep. 506 (1890). 
the plaintiff or someone in privity ${ }^{10}$ with him. This burden would not be sustained, however, if the defendant had entered of his own volition, ${ }^{11}$ nor if the plaintiff had not intended ${ }^{12}$ to beguile the defendant. The determination of these issues, thus, obviously involves complex evidentiary problems concerning the intent of the parties, a difficulty which may well explain the apparent lack of judicial uniformity in this area.

By narrowly limiting their consideration to the presence or absence of the technical elements of fraud, the courts may, moreover, often effectively lend sanction to conduct at least as reprehensible ${ }^{13}$ as that

10 "To invalidate process lawful in form because the defendant is not a resident of the jurisdiction of the court, it must appear that he has been brought into the jurisdiction by fraud to which the plaintiff was privy. . . . Any more stringent rule would require a plaintiff, before causing service of a writ upon defendant whom he finds within the jurisdiction, to inquire how he came there. ... . To impose such a burden upon a suitor seems to us unreasonable." Ex parte Taylor, 29 R.I. 129, 132, 69 Atl. 553, 554 (1908). In Steiger v. Bonn, 4 Fed. 17, 19 (C.C.D.N.J. 1880) the court said, "The only question is whether the facts shown are sufficient to identify the plaintiff with, and hold him responsible for, the deception and fraud used to lure the defendant into the state." And in Blandin v. Ostrander, 239 Fed. 700 (2d Cir. 1917) it was said that it is enough that the representations were ". . . by one acting in his [plaintiff'] behalf."

${ }^{12}$ In Strong v. Strong, 299 P.2d 148 (1956), the decisive question was whether plaintiff's invitation was the inducement or whether defendant came out of a parental desire to see his children. If the latter could be proved, the court would exercise its jurisdiction. Similarly, in Voltz v. Tutt, 12 Ky. L. Rep. 506 (1890), the vital distinction was whether defendant came in response to plaintiff's message or whether he came on business of his own.

${ }^{12}$ This is best explained in Guzzetta v. Guzzetta, 137 N.E.2d 419, 421 (Ohio 1956): "To vitiate the personal service of summons upon a person in a foreign jurisdiction who is in the jurisdiction in response to an invitation extended to him by a party to the action, an intent to trick and deceive him into coming for such purpose must have existed in the mind of the sender and the invitation itself must have been a part of the device or artifice employed to get the defendant into the foreign jurisdiction for the purpose of serving him with summons." Similar rationale is found in Suhay v. Whiting, 96 N.E.2d 609 (Ohio Com. Pl. 1950); Taylor v. McCool, 183 Tenn. 1, 189 S.W.2d 817 (1945); and in Columbia Placers Co. v. Bucyrus Steam Shovel and Dredge Co., 60 Minn. 142, 145, 62 N.W. I15, 116 (1895) the court said the "good faith" of the plaintiff is the key factor. But cf. Jaster v. Currie, 198 U.S. 144, 148 (1905), wherein the court said "He [plaintiff] arbitrarily could unite the two acts [i.e., the deposition and service of process] and do the first because he hoped it would give him a chance to do the last." Watkins v. North American Land and Timber Co., 20 'T.L.R. 534 (1904).

It is a universally accepted rule that the plaintiff's good faith will be presumed until the contrary is proved "to the satisfaction of the mind." Guzzetta v. Guzzetta, supra at 421 ; and similarly, Crandall v. Trowbridge, 170 Iowa 155, 150 N.W. 669 (1915); Kelly v. Citizens Farmers National Bank of Chickasha, 174 Okla. 1380,50 P.2d 734 (1935).

${ }^{18}$ See cases cited note 7 supra. (Those wherein no fraud or trick was found.) And 
interdicted by strict application of their formal test. Thus, the courts may countenance the otherwise fraudulent conduct of the plaintiff which has the barest color of bona fides. ${ }^{14}$ Similarly, the courts may find no fraud where the plaintiff has conspired with a defendant other than the complaining defendant, ${ }^{15}$ or where the defendant's presence has been procured by "lawful means." Furthermore, if the defendant remains in the jurisdiction beyond a "reasonable" period of time, the fraud which initially induced his entry may no longer be viewed as the proximate cause of his presence. ${ }^{17}$ And if the defendant should have known of

see Atlantic \& Pacific Telegraph Co. v. Baltimore \& Ohio R. Co., r4 Jones \& Sp. 377 (N.Y. 1880); Gumperz v. Hofman, 245 App. Div. 622, 283 N.Y. Supp. 823 (1935), noted in 49 HARv. L. REv. 844 (1936), 20 MiNN. L. REv. 686 (1936); Ex parte Sellars, 250 Ala. 84, 33 So.2d 349 (1948) wherein the defendant was already within plaintiff's jurisdiction and the fraud was designed to cause defendant to come to another part of the same jurisdiction or to remain there long enough to be served. The courts explain their approval of this fraud by saying there is no inducement from one jurisdiction to another as required by the "fraud test" and second, that defendant has a duty to make himself available for service.

${ }^{14}$ See Watkins v. North American Land \& Timber Co., 20 T.L.R. 534, 536 (1904). Generally, however, performance will not vitiate the trickery. Cavanagh v. Manhattan Transit Co., 133 Fed. 818 (C.C.D.N.J. 1905); Fidelity \& Deposit Co. of Maryland v. Bussa, 207 La. 1042, 22 So.2d 562 (1945); Ultcht v. Ultcht, 126 Atl. 440 (Ct. of N.J.Ch. 1924); Peel v. January, 35 Ark. 331 (1880).

${ }^{15}$ See Knoxville Bank \& Trust Co. v. Mershon, 153 Ky. $169,174,153$ S.W. 238 , 241 (1913), in which the court said, "If he [defendant] had a right to go there [into plaintiff's jurisdiction] on pleasure, knowing the process would be served, can it make any difference that he went for the purpose of being served? And if not, can it make any difference that there was an agreement beforehand ..." that they do this?

${ }^{10}$ In National Paper Corp. v. Scheek, 47 Lack Jur. 189 , 193 (County Ct., Pa. 1946), a case that permitted the use of a director's meeting by the plaintiffs to obtain jurisdiction of the defendant, the court said: "However the locating of the meeting here was legal. It was undoubtedly a dirty trick and with a motive far from whole. some. But we cannot see where it amounts to fraud, or misrepresentation or artifice. The motive behind the meeting here did not render it illegal." See also Iams v. Tedlock, 110 Kan. 510, 204 Pac. 537 (1922); and and in Jaster v. Currie, 198 U.S. 144, 148 (1905), the case on which the preceding cases rely, the court said that the case was no exception to the general rule that doing an act lawful in itself (taking a deposition) as a means of doing another act (service of process) lawful in itself cannot make a wrong by the combination; and notice how the court sanctioned an obvious sham in Duringer v. Moschino, 93 Ind. 495 ( 1883 ), where the plaintiff began attachment proceedings, requested defendant to defend, and when the defendant complied, service was made upon him.

${ }^{27}$ This test is a logical counterpart to the general rule in that since the defendant cannot be served when induced into plaintiff's jurisdiction by trickery or fraud, there must be a time after which the trickery will no longer be a defense. Otherwise a defendant would remain immune from service for a particular cause of action forever. The "unreasonable time" test is set forth in Olean St. Ry. Co. v. Fairmount Const. Co., $55^{\circ}$ App. Div. 292, 67 N.Y. Supp. 165 (1900). See also Klaiber v. Frank, 9 N.J. I, 
the danger, the plaintiff's wiles in luring him into the jurisdiction may not constitute a valid defense. ${ }^{18}$

To resolve the doubts and cure the possible inequities inherent in the operation of the general rule, therefore, it is submitted that the courts must adopt one of two alternatives. First, if a court decides as a matter of policy to condition its entertainment of cases on the method in which jurisdiction was obtained, such determinations should turn on the peculiar facts and circumstances of each case, and not on a rote formula. This procedure would not only more effectively deter questionable conduct, but would also confine judicial attention to matters that have little or no relation to the jurisdictional problem.19

A second and more far-reaching alternative would require the court, having found reprehensible conduct by a plaintiff in obtaining jurisdiction in a particular case, further to inquire whether or not injustice would result if that jurisdiction were to be exercised. Factors which might enter this determination would be the convenience of the forum with regard to the immediate parties, the proximity of witnesses, and the availability of evidence. In addition, it might be necessary to consider whether the assumption of jurisdiction would frustrate such sound

86 A.2d 679 (1952); Kelly v. Citizens Farmers National Bank of Chickasha, 174 Okla. 1380, 50 P.2d 734 (1935); Suhay v. Whiting, 96 N.E.2d 609 (Ohio Com. Pl. 1950).

${ }^{18}$ In Allen v. Betterly, 328 App. Div. 907, I6 N.Y.S.2d 319 (1939) the court listed those considerations which are determinative of whether the defendant should have been "aware" that there was a likelihood of service upon him. The same consideration appears to be important in other decisions: Suhay v. Whiting, 96 N.E.2d 609 (Ohio Com. Pl. 1950); Iams v. Tedlock, Iro Kan. 510, 205 Pac. 537 (1922). See also Crandall v. Trowbridge, 170 Iowa 155,150 N.W. 669,673 (1915), in which the court spoke of the fact that defendant could have sent someone else in his stead. But cf. the cases of Garabettian v. Garabettian, 206 App. Div. 502, 201 N.Y. Supp. 548 (1923), and Hill v. Goodrich, 32 Conn. 588 (1858), in which the defendant responded to mysterious and anonymous invitations which would arouse suspicion in most people, but yet this factor seemed not to affect the court's determination.

${ }^{10}$ Such a rule would be based upon a standard of behavior capable of more liberal application than the "fraud test." It would be consonant with this dicta found in Olean St. Ry. Co. v. Fairmount Const. Co., 55 App. Div. 292, 67 N.Y. Supp. 165, 167 (1900): "[T] he plaintiff ought not to be permitted to take advantage of a course of conduct which, if not amounting to actual fraud and deceit, was certaintly equivalent thereto, for it involved a breach of the confidence which King (defendant) had reposed in the bona fides of the invitation of plaintiff's president to place himself within the jurisdiction of the court." And yet the rule would go further in that it would not be limited to situations where the plaintiff invites the defendant into plaintiff's jurisdiction. It would apply in any case where the court feels the defendant is a victim of unscrupulous behavior on the part of the plaintiff. 
policies as that which favors the amicable settlment of disputes, ${ }^{20}$ or that which protects an individual's statutory rights to be sued in a particular venue. $^{21}$ This procedure would shift judicial attention from questions of the plaintiff's misconduct to those bearing more directly on the jurisdictional problem.

Adoption of either of these suggested alternatives would posit decisions in this area on a more rational and supportable basis.

${ }^{20}$ Thus far a few courts have so reasoned. In State ex rel. Ellan v. Dist. Ct., 97 Mont. 160, 170, 172, 33 P.2d 526, 530, 531 (1934) the court said, "The law favors the compromise and settlement of disputed claims and should protect a non-resident who comes into this state at the solicitation of his adversary for the purpose of attempting such a disposition of a controversy, to the same extent as when one comes here as a party to, or witness in, a case in court. . . . A bona fide attempt to compromise and settle a controversy without the trouble and expense of the institution of a suit and the trial of a cause in a more important step in connection with the cause than argument of a demurrer or the taking of a deposition for the preservation of testimony and the general rule as to immunity should be extended to cases wherein, as here, a party to a controversy has been induced for this purpose to come within rifle range, as it were, under a fiag of truce; honor and fair dealing should dictate that such a person be permitted a reasonable time within which to return to safety of the position from which he was induced to withdraw, before his adversary goes into action." Similarly, see Kelly v. Citizens Farmers National Bank of Chickasha, 174 Okla. 1380, 50 P.2d 734 (1935). But of. Union Sugar Refinery v. Mathieson, 2 Cliff. 304, 24 Fed. Cas. 68I (C.C.D. Mass. 1864) where the sole purpose of defendant's presence in plaintiff's jurisdiction was to obtain a settlement and yet the court permitted service and exercised its jurisdiction.

${ }^{21}$ See Nicholson v. Gulf, Mobile \& Northern R. Co., 177 Miss. 854, 72 So. 306, 309 (1937) wherein the court said, "The right of a defendant to be sued in the venue fixed by statute is too valuable to permit it to be destroyed at the whim or will, or for the convenience of the plaintiff. . . A lawful act does not become unlawful merely because it may be done by agreement between two parties (Here plaintiff and one of several defendauts conspired to get the others.); but if the purpose and result of the act is to defeat and destroy a right guaranteed by law to another the act becomes fraudulent in its nature." See also Taylor v McCool, 183 Tenn. 1, 189 S.W.2d 817, 822 (1945) in which the right protected was the right to be sued in a certain county. 